\title{
The Ribonucleotide Sequence of 5S rRNA from Two Strains of Deep-Sea Barophilic Bacteria
}

\author{
By J. W. DEMING,${ }^{1}+$ H. HADA,${ }^{1}$ R. R. COLWELL,${ }^{1 *}$ K. R. LUEHRSEN ${ }^{2}$ \\ AND G. E. FOX ${ }^{2}$ \\ ${ }^{1}$ Department of Microbiology, University of Maryland, College Park, Maryland 20742, USA \\ ${ }^{2}$ Department of Biochemical and Biophysical Sciences, University of Houston, Central Campus, \\ Houston, Texas 77004, USA
}

(Received 23 February 1984; revised 21 March 1984)

\begin{abstract}
Deep-sea bacteria were isolated from the digestive tract of animals inhabiting depths of $5900 \mathrm{~m}$ in the Puerto Rico Trench and $4300 \mathrm{~m}$ near the Walvis Ridge. Growth of two bacterial strains was measured in marine broth and in solid media under a range of pressures and temperatures. Both strains were barophilic at $2{ }^{\circ} \mathrm{C}\left( \pm 1{ }^{\circ} \mathrm{C}\right)$ with an optimal growth rate of $0.22 \mathrm{~h}^{-1}$ at a pressure $30 \%$ lower than that encountered in situ. At 1 atm they grew at temperatures ranging from 1.2 to $18.2{ }^{\circ} \mathrm{C}\left( \pm 0.3{ }^{\circ} \mathrm{C}\right)$, while in situ pressures increased the upper temperature limit to $23.3^{\circ} \mathrm{C}$. Both strains were identified as members of the genus Vibrio, based on standard taxonomic tests and $\mathrm{mol} \% \mathrm{G}+\mathrm{C}$ values $(47 \cdot 0$ and $47 \cdot 1)$. Ribonucleotide sequences determined for 5S ribosomal RNA from each strain confirmed relationship to the Vibrio-Photobacterium group, as represented by $V$. harveyi and $P$. phosphoreum, but the barophiles were clearly distinct from these species. Secondary structure conformed to the established model for eubacterial $5 S$ rRNA.
\end{abstract}

\section{INTRODUCTION}

Barophilic bacteria are micro-organisms that grow either preferentially or exclusively under elevated hydrostatic pressures. Evidence for their existence was first observed in sediment samples retrieved from the abyssal ocean, an environment characterized by elevated hydrostatic pressure and low temperature (ZoBell \& Morita, 1957). More than two decades passed, however, before sampling devices and culturing methods were developed and used successfully in the collection and maintenance of deep-sea, barophilic bacteria in pure culture (Yayanos $e t$ al., 1979; Deming \& Colwell, 1981 ; Jannasch et al., 1982). Barophiles have now been isolated in pure culture from a variety of deep-sea habitats, including decomposing abyssal amphipods (Yayanos et al., 1979, 1981, 1982), digestive tracts of abyssal amphipods and holothurians (Deming et al., 1981; Deming \& Colwell, 1981), faecal material and sediments deposited on the deep ocean floor (Deming \& Colwell, 1982; J. W. Deming, unpublished results), and the deepsea water column (Jannasch et al., 1982). These findings, in conjunction with results of field studies of natural assemblages of deep-sea bacteria (Schwarz et al., 1976; Tabor et al., 1982; Deming \& Colwell, 1982), suggest that the distribution and activity of barophilic bacteria in the deep sea may be more widespread and, therefore, of greater ecological significance than previously believed.

Essentially no information is available on the physiology, taxonomy or molecular genetics of the deep-sea barophiles now available in pure culture, apart from documentation of their barophilic nature and, in two cases, of their sensitivity to elevation of temperature (Yayanos $e t$ al., 1981; Yayanos \& Dietz, 1982). Therefore, we initiated laboratory studies of two strains of

† Present address: Chesapeake Bay Institute and Department of Biology, The Johns Hopkins University, 4800 Atwell Road, Shady Side, Maryland 20764, USA. 
barophilic bacteria, designated UM40 and W145, isolated from the digestive tract of abyssal animals (Deming et al., 1981). We report here the results of growth studies at a range of temperatures and pressures and the results of taxonomic and molecular analyses of these strains, including a comparison of the nucleotide sequence of their 5 S ribosomal RNAs with those of non-barophilic bacteria.

\section{METHODS}

Isolation procedures. Bacterial strain UM40 was isolated from the digestive tract of an abyssal scavenging amphipod, Scopelocheirus shellengi, captured in a free-vehicle trap at a depth of $5920 \mathrm{~m}$ in the Puerto Rico Trench (Deming et al., 1981). The amphipod was exposed only briefly to warm surface waters, since the trap was recovered shipboard within 15 min after it had surfaced. The amphipod was immediately placed on an ice tray lined with sterile foil and dissected, using aseptic methods described elsewhere (Deming et al., 1981). The entire digestive tract was removed, macerated, and suspended in $30 \mathrm{ml}$ of filtered $(<0.2 \mu \mathrm{m})$, autoclaved, artificial seawater (Marine Mix, Utility Chemical Co., Paterson, NJ, USA), prechilled in an ice bath. The gut suspension was loaded into a sterile syringe, housed within a fluid-filled pressure vessel (also prechilled in an ice bath), and pressurized to $590 \mathrm{~atm}$, the in situ pressure at the depth from which the animal was captured. Thus, the sample was exposed to pressures less than that encountered in situ for a limited period of several hours, and to temperatures above that encountered in situ $\left(<4^{\circ} \mathrm{C}\right)$ for less than $1 \mathrm{~h}$.

The assembled, pressurized vessel was packed in ice and shipped to the laboratory at the University of

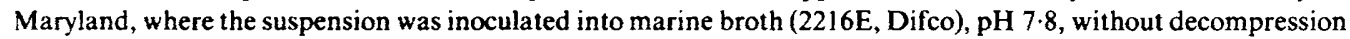
or warming, using the transfer system described by Tabor $e t$ al. (1981) and Deming (1981). A series of seven additional decompression-free transfers into fresh cold broth was completed during the course of an 8 month incubation period in a cold room maintained at $3{ }^{\circ} \mathrm{C}\left( \pm 2^{\circ} \mathrm{C}\right)$. At the end of this selective culturing process, the sample was decompressed and plated on to marine agar (2216E, Difco). After incubation for 3 weeks at $3{ }^{\circ} \mathrm{C}$ and atmospheric pressure ( $1 \mathrm{~atm})$, uniform colony morphology was observed on the plates. A colony was picked and purified by serial transfer, again using incubation conditions of $3{ }^{\circ} \mathrm{C}$ and $1 \mathrm{~atm}$. The strain was cultured in marine broth. examined by Gram stain for purity, and inoculated on to marine agar slants for storage at $3^{\circ} \mathrm{C}$ and $1 \mathrm{~atm}$. The culture was also inoculated into the silica gel medium of Dietz \& Yayanos (1978) that solidified after inoculation. Silica gel pour tubes were incubated at $3{ }^{\circ} \mathrm{C}$ and $20^{\circ} \mathrm{C}$ at $1 \mathrm{~atm}$, and at $3{ }^{\circ} \mathrm{C}$ under $590 \mathrm{~atm}$ (in situ pressure of the original sample).

Bacterial strain W145 was isolated from posterior intestinal scrapings of an abyssal, deposit-feeding holothurian, Psychropotes longicauda, retrieved by beam trawl from a depth of $4575 \mathrm{~m}$ near the Walvis Ridge in the South Atlantic Ocean. Cold mud trapped in the trawl net surrounded and protected the animal against mechanical damage and exposure to warm surface-water temperatures during retrieval operations. Shipboard procedures, including aseptic dissection of the animal specimen, have been described elsewhere (Deming et al., 1981). Although care was taken to avoid temperature increases above $4^{\circ} \mathrm{C}$, no attempts were made to limit the length of time the sample was exposed to pressures less than that encountered in situ. Strain W145 was selected at random from a plate of marine agar inoculated with gut scrapings and incubated at $3^{\circ} \mathrm{C}$ and $1 \mathrm{~atm}$. After three transfers under the same incubation conditions, the strain was cultured in marine broth, examined by Gram stain for purity, inoculated on to marine agar slants and stored at $3^{\circ} \mathrm{C}$ and 1 atm for 11 months prior to testing for growth under pressure.

Thick suspensions of UM40 and W 145 were prepared in $1.0 \mathrm{ml} 5 \%(\mathrm{v} / \mathrm{v})$ glycerol-nutrient broth (Difco) and kept in liquid nitrogen at $-196^{\circ} \mathrm{C}$. The strains are available for distribution from Professor R. R. Colwell.

Tests for barophilic growth. Relative growth rates at atmospheric and in situ hydrostatic pressures were determined by examining colony size in duplicate silica gel pour tubes incubated for equivalent time periods at $3{ }^{\circ} \mathrm{C}\left( \pm 2{ }^{\circ} \mathrm{C}\right)$ at the selected pressures. Pure cultures freshly inoculated into marine broth, $\mathrm{pH} 7 \cdot 8$, at $3{ }^{\circ} \mathrm{C}$ were also monitored over a $5 \mathrm{~d}$ incubation period at both atmospheric and in situ pressures, following the procedures used by Deming et al. (1981). Growth under in situ pressure was monitored by distributing the culture into separate pressure vessels, each of which was decompressed at a selected interval during the total incubation period. Bacterial concentrations in decompressed samples and in samples incubated at $1 \mathrm{~atm}$ were determined by enumerating total colony-forming units (c.f.u.) on marine agar plates incubated at $3{ }^{\circ} \mathrm{C}$ and $1 \mathrm{~atm}$.

Growth rates of strains UM 40 and W 145 were also calculated from the exponential portion of growth curves generated in marine broth, $\mathrm{pH} 7 \cdot 8$, at $2{ }^{\circ} \mathrm{C}\left( \pm 1^{\circ} \mathrm{C}\right)$ and six different pressures, including pressures lower than, equivalent to, and greater than those encountered at the ocean depths from which the bacteria were retrieved. These studies followed the procedures of Yayanos et al. (1981), in which the culture was monitored at each pressure using a separate pressure vessel that was decompressed for each subsampling event, repressurized within 1-2 min, and returned to a rocking platform in a cold water bath. Decompressed subsamples were fixed immediately in artificial seawater containing $0.05 \%(\mathrm{w} / \mathrm{v})$ sodium azide and $0.25 \%(\mathrm{v} / \mathrm{v})$ formalin for analysis of bacterial concentrations using a Coulter counter model ZBI (Coulter). 
Tests for psychrophilic growth. Marine agar plates, marine broth, silica gel pour tubes, and a seawater-based O-F medium (Difco) were inoculated with strains UM40 and W145 and incubated at both $3{ }^{\circ} \mathrm{C}$ and $20^{\circ} \mathrm{C}$ at 1 atm. A more detailed analysî of temperature growth ranges under pressures of 1, 204, 408, and 612 atm was obtained using the polybarothermostat of Yayanos (1982). This device allows for incubation of a given organism at pressure along a temperature gradient. A culture of each strain in marine broth at $2{ }^{\circ} \mathrm{C}, \mathrm{pH} 7 \cdot 8$, was mixed with gelatin at $25^{\circ} \mathrm{C}$ at a volume ratio of $2: 1$, which dropped the temperature to about $12^{\circ} \mathrm{C}$ and initiated solidification of the medium. Final gelation occurred after the culture was loaded into polybarothermostat tubes $(0.8 \times 75 \mathrm{~cm})$, prechilled to $2{ }^{\circ} \mathrm{C}$. Individual tubes were placed in an aluminium block along a temperature gradient of $-4 \cdot 2^{\circ} \mathrm{C}$ to $24.5^{\circ} \mathrm{C}\left( \pm 0.3{ }^{\circ} \mathrm{C}\right)$ and compressed to the desired pressure. After an $11 \mathrm{~d}$ incubation period, each tube was decompressed and examined using a dissecting microscope ( $100 \times$ magnification). The two sharply defined points (and therefore temperatures) along the length of each tube, between which abundant c.f.u. and beyond which no c.f.u. were observed, were recorded as the minimum and maximum growth temperatures for each pressure tested.

Taxonomic tests. Bacterial strains UM40 and W145 were identified to genus level based on results of the following tests : micromorphology on marine agar; Gram stain; oxidase (Kovacs, 1956); motility in wet mount; and oxidation/fermentation reaction in glucose (Hugh \& Leifson, 1953), using a seawater-based O-F medium (Difco). For the latter, inoculated $\mathrm{O}-\mathrm{F}$ tubes were incubated at $1 \mathrm{~atm}$ and $3{ }^{\circ} \mathrm{C}$. Growth and production of acid were recorded daily for 3 weeks.

DNA base ratio (mol \% G $+\mathrm{C}$ ) was also determined, according to the methods of Mandel et al. (1970). DNA was extracted, using the procedures of Marmur \& Doty (1962), from batch cultures incubated at $3^{\circ} \mathrm{C}$ and $1 \mathrm{~atm}$. All steps in the extraction procedure required strict maintenance of low temperature $\left(3{ }^{\circ} \mathrm{C}\right)$ for isolation of the DNA.

Sequencing of $5 S$ ribosomal RNA. Turbid broth cultures of strains UM40 and W145 were plated on marine agar and incubated at $3^{\circ} \mathrm{C}$ and 1 atm for 3 weeks. A $2 \mathrm{~g}$ 'paste' of each strain was harvested using a sterile rubber spatula. The cells were broken by sonication and a crude ribosomal RNA preparation obtained by phenol extraction (Woese et al., 1975). $5 \mathrm{~S}$ rRNA was purified by electrophoresis for $3 \mathrm{~h}$ at $400 \mathrm{~V}$ on a $20 \times 20 \times 0.02 \mathrm{~cm}$ $3.5 \% / 10 \%$ composite polyacrylamide slab gel in a $7 \mathrm{M}$-urea, $50 \mathrm{~mm}$-Tris, $50 \mathrm{~mm}$-boric acid, $1 \mathrm{~mm}$-EDTA buffer. The RNA bands were located by ultra-violet shadowing (Hassur \& Whitlock, 1974). The gel segment containing the 5S rRNA was excised with a razor blade and the RNA was eluted by the crush and soak method (Maxam \& Gilbert, 1977). $T_{4}$ polynucleotide kinase was used to end-label (Chaconas \& Van de Sande, 1980) either dephosphorylated whole 5S rRNA or the large fragment produced by ribonuclease $\mathrm{T}_{2}$ digestion of whole 5S rRNA (Meyhack et al., 1977; Jordan, 1971). The 3' end-labelling procedure utilized $\mathrm{T}_{4}$ RNA ligase (England et al., 1980). Sequencing ladders were generated by the enzymic method (Donis-Keller et al., 1977) and the chemical method (Peattie, 1979). In the enzymic method, pyrimidine detection was improved by use of endonuclease phy-M from Physarum polycephalum (Donis-Keller, 1980). Improved resolution near the 5 ' terminus was obtained by extension with six adenines prior to end-labelling (Luehrsen \& Fox, 1981 a). The terminal nucleotide was identified as described elsewhere (Luehrsen \& Fox, $1981 b$ ). All sequencing ladders were run on either $12 \%$ or $20 \%$ thin $(0.02 \times$ $40 \times 20 \mathrm{~cm}$ ) polyacrylamide gels at $2.0 \mathrm{kV}$.

Phylogenetic tree construction. To gain insight concerning the phylogenetic position of the barophilic strains, a tree was constructed which included published 5S rRNA sequences from a variety of Gram-negative bacteria (Brownlee et al., 1968; Woese et al., 1975; Luehrsen \& Fox, 1981 b; MacKay et al., 1982; Newhouse et al., 1981; Dams et al., 1983; Komiya et al., 1983; K. R. Luehrsen, unpublished results). Tree construction utilized the method of $\mathrm{Li}$ (1981). Individual binary differences were calculated directly from aligned sequences. Each individual difference was assigned unit value. Insertion/deletion events were rare and never amounted to more than a single base at a time. When encountered, these were recorded as unit differences. Alignment, indicated in Fig. 2, takes into account known universal and conserved positions (Delihas \& Anderson, 1982; De Wachter $e$ t al., 1982; Kuntzel et al., 1983), as well as the most well established secondary structural features (Fox \& Woese, 1975; Studnicka et al., 1981; Delihas \& Anderson, 1982).

\section{RESULTS}

\section{Tests for barophilic and psychrophilic growth}

Both strains always grew more rapidly under elevated pressures than at $1 \mathrm{~atm}$. Pinpoint colonies appeared in silica gels incubated at atmospheric pressure, while 1-2 mm diameter colonies formed in gels incubated at elevated in situ pressures for an equivalent time period. When several of the gels held at 1 atm were incubated for an additional 4 weeks under pressure (590 atm), a majority of the colonies doubled in size, compared to duplicate gels held at $1 \mathrm{~atm}$.

Bacterial growth rates measured in pressurized broth cultures, whether or not exposed to repeated decompression/recompression cycles, were more rapid than those measured at $1 \mathrm{~atm}$. 


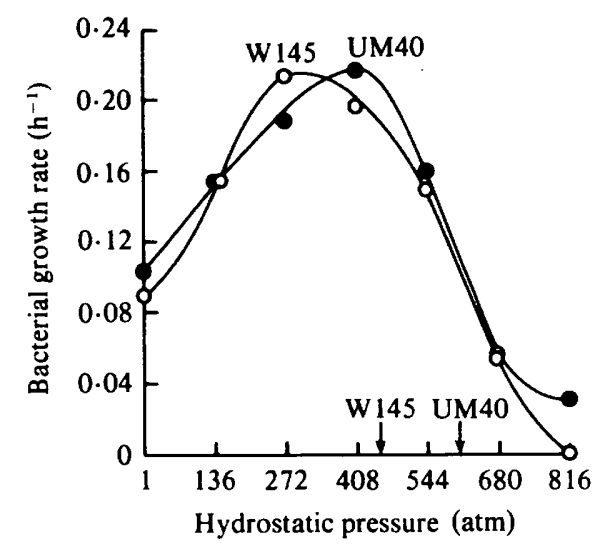

Fig. 1. Growth rates of bacterial strains UM40 (O) and W145 $(O)$ cultured in marine broth, pH 7.8, at $2{ }^{\circ} \mathrm{C}\left( \pm 1^{\circ} \mathrm{C}\right)$ and $1,136,272,408,544,680$ and $816 \mathrm{~atm}$ pressure. Rates were calculated from the exponential portion of each growth curve, using linear regression analysis. Values of $r^{2}$ averaged 0.992. Arrows indicate the approximate pressure encountered at the depth from which the bacteria were recovered.

Table 1. Temperature ranges for bacterial growth under hydrostatic pressures of 1 to $612 \mathrm{~atm}$

Growth was assayed by colony formation in a solid growth medium inoculated prior to solidification and pressurization. See text for details.

$\begin{array}{lcccc}\text { Strain } & \begin{array}{c}\text { Pressure } \\ \text { (atm) }\end{array} & \overbrace{\text { Minimum }} & \text { Maximum } & \text { Range } \\ \text { UM40 } & 1 & 3.0 & 18 \cdot 2 & 15 \cdot 2 \\ & 204 & 2 \cdot 2 & 22 \cdot 4 & 20 \cdot 2 \\ & 408 & 2 \cdot 4 & 23 \cdot 3 & 20.9 \\ \text { W145 } & 612 & 4 \cdot 6 & 23 \cdot 3 & 18 \cdot 7 \\ & 1 & 1 \cdot 2 & 14 \cdot 8 & 13 \cdot 6 \\ & 204 & 1 \cdot 1 & 20.4 & 19 \cdot 3 \\ & 408 & 2 \cdot 2 & 22 \cdot 2 & 20.0 \\ & 612 & 4 \cdot 3 & 16.7 & 12.4\end{array}$

Results of growth experiments at $2^{\circ} \mathrm{C}\left( \pm 1^{\circ} \mathrm{C}\right)$ and seven different pressures are given in Fig. 1 . The bell shape of the curves, with peak growth rates occurring at pressures well above $1 \mathrm{~atm}$, clearly demonstrates the barophilic nature of these bacteria. Strain UM40, recovered from a greater depth in the ocean than W145, required higher pressures for optimal growth. In both cases, however, optimal growth rates were measured at pressures about $30 \%$ lower than those encountered at the depth of collection, a pattern also observed by Yayanos et al. (1982). Generation times ranged from $4.6 \mathrm{~h}$ at $410 \mathrm{~atm}$ to $32 \mathrm{~h}$ at $816 \mathrm{~atm}$ for UM40, and from $4.7 \mathrm{~h}$ at $300 \mathrm{~atm}$ to no detectable growth at $816 \mathrm{~atm}$ for W145.

Both organisms proved to be psychrophilic at atmospheric pressure, since no growth was detected in any of the solid or liquid media incubated at $20^{\circ} \mathrm{C}$. However, incubation in solid media under elevated pressures close to those encountered in situ resulted in an expanded temperature growth range expressed largely at the upper end of the scale, where temperature maxima were shifted $5-7^{\circ} \mathrm{C}$ above those observed at $1 \mathrm{~atm}$ (Table 1).

\section{Taxonomic characteristics}

Based on the identification schemes of Bain \& Shewan (1968) and Gibson et al. (1977), and in Bergey's Manual of Determinative Bacteriology (Buchanan \& Gibbons, 1974), bacterial strains 

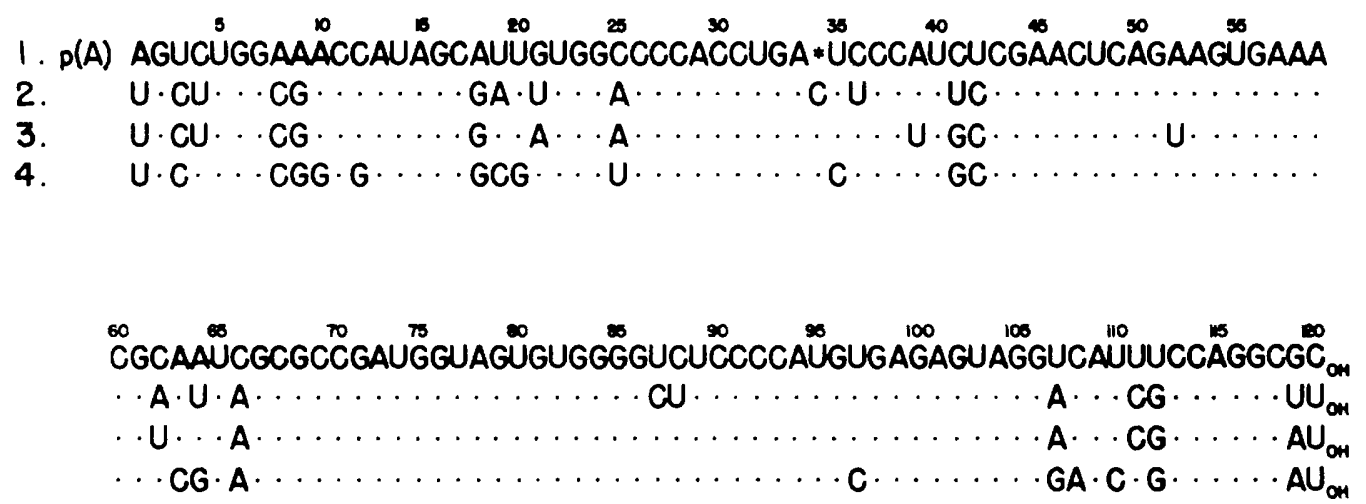

Fig. 2. The primary ribonucleotide sequence for $5 \mathrm{~S}$ rRNA of (1) barophilic bacterial strains UM40 and W145 (sequences identical) compared to (2) Vibrio harveyi (Luehrsen \& Fox, 1981 b), (3) Photobacterium phosphoreum (Woese \& Fox, 1975), and (4) Escherichia coli (Brownlee et al., 1968). Letters indicate binary differences between UM40 and W145 and the other three strains: 23 differences with $V$. harveyi, 19 with $P$. phosphoreum, and 23 with $E$. coli. The numbering system is based on the $E$. coli sequence.

UM40 and W145 can be classified as members of the genus Vibrio. Both strains were Gramnegative, short, curved rods, $0.5 \mu \mathrm{m}$ wide and $1.5-3.0 \mu \mathrm{m}$ long, motile by polar flagella, oxidasepositive, and non-pigmented on solid medium. At $3{ }^{\circ} \mathrm{C}$ (neither strain grew in O-F media at room temperature and atmospheric pressure), both strains utilized glucose oxidatively and fermentatively, but did not produce gas. The DNA base ratios were determined to be $47 \cdot 1 \pm$ $0.7 \mathrm{~mol} \% \mathrm{G}+\mathrm{C}$ for strain UM40, and $47.0 \pm 0.8 \mathrm{~mol} \% \mathrm{G}+\mathrm{C}$ for strain W145.

\section{$5 S$ rRNA sequence and phylogenetic relationships}

The ribonucleotide sequences determined for $5 \mathrm{~S}$ rRNA were identical, suggesting that both strains are members of the same species. As is usual in 5S rRNA sequencing, no attempt was made to detect either post-transcriptional modifications or microheterogeneities (the presence of molecules of different length in the $5 \mathrm{~S}$ rRNA population). There are two points of uncertainty in the sequence. There may be a second adenine at the $5^{\prime}$ terminus and the number of cytosines beginning at position 25 may be three instead of four. The latter point was not resolved by either $5^{\prime}$ or $3^{\prime}$ gels. However, there was no evidence for a non-cytosine base in this stretch. Thus, the only viable alternative to a cytosine at position 25 is a deletion.

The complete 5S rRNA sequence for the barophiles, juxtaposed with known sequences for Vibrio harveyi, the only other Vibrio sp. for which the $5 \mathrm{~S}$ rRNA sequence is available (Luehrsen \& Fox, 1981 b), Photobacterium phosphoreum, a luminescent marine organism (Woese et al., 1975), and Escherichia coli, a representative enteric organism (Brownlee et al., 1968), is presented in Fig. 2. The number of nucleotide differences in the sequence of 5S rRNA from the barophilic strains, compared with $V$. harveyi, $P$. phosphoreum and $E$. coli is 23,19 , and 23 , respectively. Fig. 3 shows the phylogenetic position of the barophilic strains among the Gram-negative bacteria based on $5 \mathrm{~S}$ rRNA sequence data.

The strong agreement with which the sequence conforms to widely accepted 5S rRNA secondary structural features is illustrated in Fig. 4. The dotted lines indicate two base pairs proposed by Studnicka et al. (1981) which are still regarded as somewhat tentative due to the limited amount of comparative evidence. The cytosine at position 25 and the number of adenines at the $5^{\prime}$ terminus are tentative as discussed above. The sequence of the barophilic strains conforms exactly to this model. Recently it has been argued (De Wachter et al., 1982) that a five helix model is produced by building a new helix with the two dotted base pairs of this figure as a nucleus. Since the barophiles are identical in sequence to $E$. coli in the pertinent regions our data do not provide a comparative test of this idea. Thus, if one believes the five helix model is applicable to $E$. coli SS rRNA, then one would also find the sequence of the barophiles to be in complete accordance. 


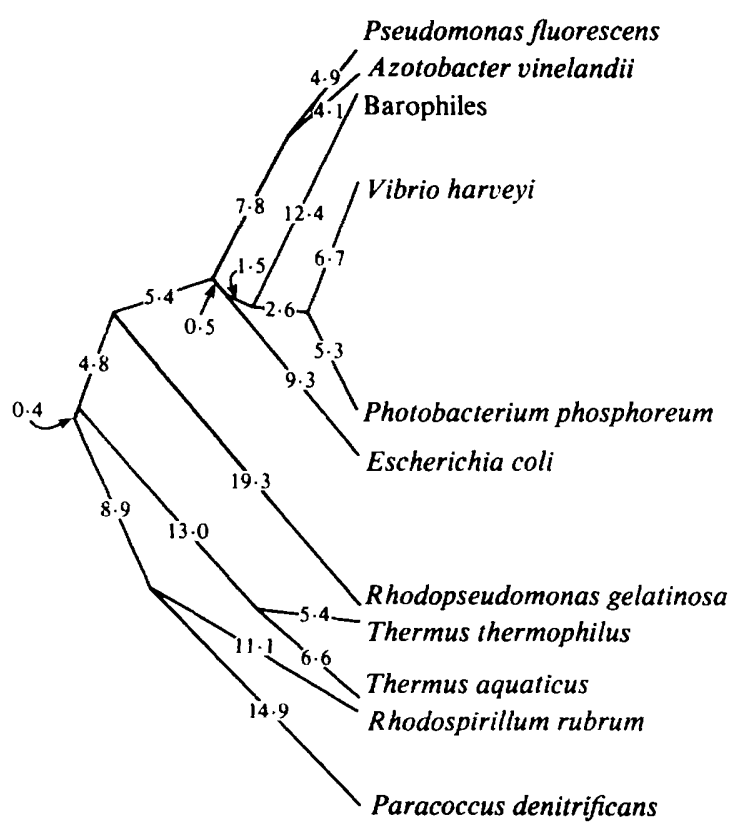

Fig. 3. Phylogenetic tree for Gram-negative bacteria based on $5 S$ rRNA sequence data. Numbers on the figure indicate branch lengths in nucleotide differences. (After the method of $\mathrm{Li}, 1981$.)

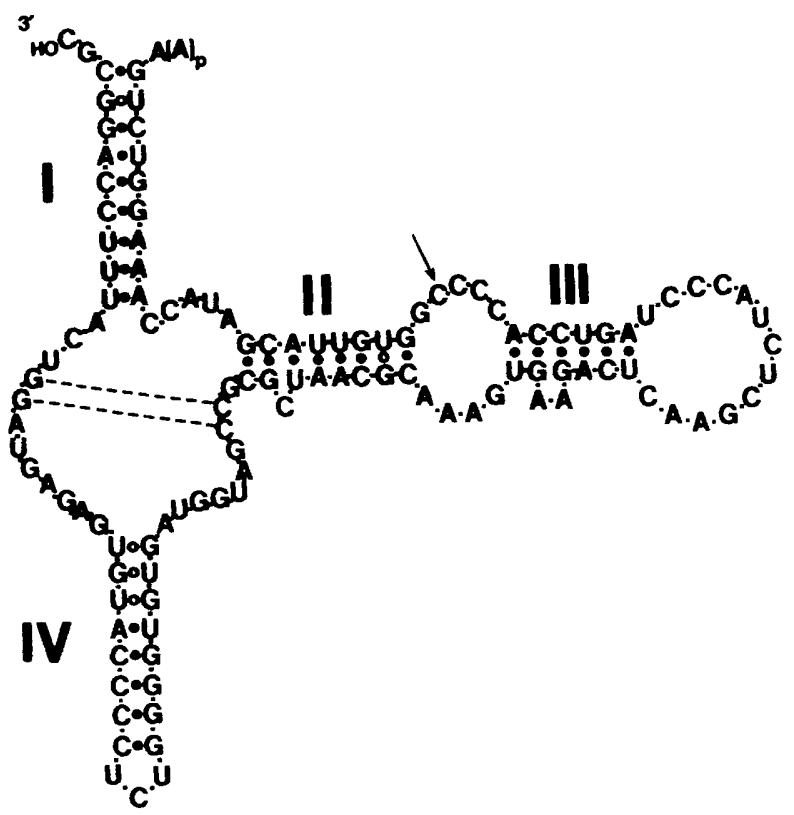

Fig. 4. Sequence of the barophilic 5S rRNA drawn in the usual four helix secondary structure model with helix extensions. See Results for details.

\section{DISCUSSION}

A variety of barophilic bacteria inhabit the deep sea, including some that grow, albeit more slowly, when decompressed to atmospheric pressure and some that fail to demonstrate growth when decompressed. The former are exemplified by strains UM40 and W145, reported in this 
study, which grew $2 \cdot 2$ to $2 \cdot 4$ times faster at optimal pressures than at $1 \mathrm{~atm}$, and by other strains, reported by Yayanos et al. $(1981,1982)$, which grew 1.1 to about 10 times faster at optimal pressures. The latter are exemplified by the obligate barophile, strain MT-41, which cannot reproduce at $1 \mathrm{~atm}$ (Yayanos et al., 1981). The common ability of all of these deep-sea bacteria to grow preferentially at elevated pressures may be a very stable characteristic, closely linked to temperature. With working temperatures always kept to $4{ }^{\circ} \mathrm{C}$ or lower, neither multiple decompression/recompression cycles during growth studies nor long-term storage at atmospheric pressure resulted in a loss of the barophilic growth characteristics of the strains reported in this study.

The growth of these barophiles, at least at atmospheric pressure, was strictly psychrophilic, as defined by Morita (1976). Under elevated pressures, however, the bacteria demonstrated an expanded temperature growth range expressed largely as an upward shift in the temperature maxima. These findings raise questions about the interactive effects of temperature and pressure on the growth and metabolism of barophilic bacteria, as well as speculation about the current adaptive significance of an increased temperature growth range for bacteria that inhabit abyssal depths in the ocean where temperatures never exceed $4{ }^{\circ} \mathrm{C}$. It is intriguing to consider the interactive effects of temperature and pressure on barophiles as the subtle, residual signature of ancestral organisms that once inhabited a warm Archaean ocean (Baross et al., 1984).

Adaptations resulting in barophilic growth have probably evolved in a number of different genera (ZoBell \& Morita, 1957). Barophilic bacteria obtained in pure culture by other investigators have not yet been classified, but barophilic strains UM40 and W145 are not significantly different from non-barophilic Vibrio spp. in their response to selected, standard taxonomic tests. Many standard tests, however, were designed for bacteria that grow optimally at conditions that are hostile to psychrophilic barophiles, a compelling reason for assessing the phylogenetic position of UM40 and W145 by direct molecular analysis.

One molecular approach being used (Hori \& Osawa, 1979; Kuntzel et al., 1981, 1983) involves the comparison of 5S ribosomal RNA primary structures (Fox \& Woese, 1975; Klotz et al., 1979; Hori \& Osawa, 1979), although the 5S rRNA data base for Gram-negative bacteria is still limited. However, three major Gram-negative subgroups have been explored extensively by $16 \mathrm{~S}$ rRNA cataloguing (Fox et al., 1980; C. R. Woese, unpublished results). The first of these includes members of such genera as Aquaspirillum, Thiobacillus, Alcaligenes, and a few purple sulphur bacteria such as Rhodospirillum tenue and Rhodopseudomonas gelatinosa. The second group involves the majority of the purple photosynthetic bacteria along with non-photosynthetic strains such as Paracoccus denitrificans and Agrobacterium tumefaciens. The third group includes Pseudomonas fluorescens and other group I pseudomonads, E. coli and other enterics, Vibrio harveyi, Photobacterium phosphoreum, and various strains of Oceanospirillum. In many instances, both $5 \mathrm{~S}$ rRNA and $16 \mathrm{~S}$ rRNA data exist for identical strains. Thus, it is possible to relate the $5 \mathrm{~S}$ rRNA tree of Fig. 3 to the 16S rRNA dendrograms, and there is little doubt that the barophilic strains belong in the third group along with vibrios and enterics. Determinations of $\mathrm{G}+\mathrm{C}$ content are consistent with this conclusion.

Fig. 3 also indicates significant differences between the barophilic strains and those of the Vibrio-Photobacterium group. At the present time, 5S rRNA data exist for only two members of this group $-V$. harveyi and $P$. phosphoreum. Further refinement of the placement of the barophilic strains will require additional 5S rRNA sequences from other Vibrio and Photobacterium species. However, the application of other molecular techniques, including microcomplement fixation (Baumann et al., 1980; Bang et al., 1981), DNA/DNA hybridization (Reichelt et al., 1976), and rRNA/DNA hybridization (Baumann \& Baumann, 1977) indicate that the genera Vibrio and Photobacterium are well represented by $V$. harveyi and $P$. phosphoreum. Since the number of 5S rRNA sequence differences between the barophilic strains and $V$. harveyi (19) and $P$. phosphoreum (23) are considerably greater than the differences between $V$. harvey $i$ and $P$. phosphoreum (12), the barophiles are clearly distinct from these species and may represent a new genus. The genus $P$ seudomonas offers a related case in which the genus could be split on molecular genetic grounds (Palleroni et al., 1973), but has not been so because of a lack of phenotypic properties distinguishing the homology groups. 
The 5S rRNA data also offer an opportunity to determine whether there are any specific molecular adaptations attributable to a barophilic-psychrophilic ecological niche. Eubacterial 5S rRNAs have four helical regions (Fox \& Woese, 1975) whose length and position typically are conserved. Extensions to several of these helices (Studnicka et al., 1981; Garrett et al., 1981) are also known. Sequence comparisons have allowed identification of conserved and semiconserved nucleotides (Delihas \& Anderson, 1982; De Wachter et al., 1982; Kuntzel et al., 1983).

It is clear that the barophilic-psychrophilic niche has not necessitated any major redesign in the structure of $5 S$ rRNA in terms of either structure (Fig. 4) or sequence conservation. However, there are some unusual features of the molecule worth considering in the light of the stabilizing role that elevated hydrostatic pressure and low temperature could play. For example, helix II is apparently weakened, relative to $E$. coli, by inclusion of a number of adenine-uracil base pairs. This phenomenon has also been observed in other marine strains (Woese et al., 1975; Luehrsen \& Fox, $1981 b$ ). The question as to whether this represents a unique marine adaptation, a more general structural feature of helix II (Woese et al., 1975), or mere coincidence, remains open. This trend towards overall increased adenine plus uracil content may also contribute to the one feature unique to the barophilic strains - the occurrence of three consecutive adenine-uracil pairs at the end of helix I. Additionally, the occurrence of cytosine at position 66 is rare in 5S rRNA and surprising, in view of the aforementioned trend, since adenine is present at position 66 in $E$. coli, $P$. phosphoreum and $V$. harveyi. Also unusual is the occurrence of uracil at positions 40 and 42 , which has been observed previously only in Rhodomicrobium 5S rRNA (C. R. Woese, personal communication).

Work now in progress, including DNA/DNA hybridizations and the sequencing of 5S rRNA from other strains of Vibrio and related genera, should permit further resolution of the taxonomic position of these barophilic vibrios, hopefully providing new insight into the quest for understanding of the evolution of the genus Vibrio from the deep sea to terrestrial forms.

We thank A. Yayanos for use of his pressure equipment and laboratory facilities to complete portions of this research, A. Dietz, R. Van Boxtel, K. Jones, L. Somers, L. Brice, and G. Hallock for technical assistance, and M. MacDonell for useful discussions. Financial support for this research was provided by NSF grants OCE-7682655, DEB-82-08418, BSR-82-08418, OCE-80-09473 and PDF-8166007, NOAA grant NA7911-D-00062, and NASA grant NSG-7440.

\section{REFERENCES}

BaIN, N. \& Shewan, J. M. (1968). Identification of Aeromonas, Vibrio and related organisms. In Identifcation Methods for Microbiologists, Part B, pp. 79-84. Edited by B. M. Gibbs \& D. A. Shapton. New York: Academic Press.

Bang, S. S., Baumann, L., Woolkalis, M. J. \& BaumanN, P. (1981). Evolutionary relationships in Vibrio and Photobacterium as determined by immunological studies of superoxide-dismutase. Archives of Microbiology 130, 111-120.

Baross, J. A., Deming, J. W. \& Becker, R. R. (1984). Evidence for growth of bacteria at high temperature and pressure. In Proceedings of the Third International Symposium on Microbial Ecology. Edited by M. J. Klug. East Lansing, Michigan: American Society for Microbiology (in the Press).

BaumanN, L. \& BaumanN, P. (1977). Study of relationship among marine and terrestrial enterobacteria by means of in vitro DNA-ribosomal RNA hybridization. Microbios Letters 3, 11-20.

Baumann, L., Bang, S. S. \& Baumann, P. (1980). Studies of relationship among species of Vibrio,
Photobacterium and terrestrial enterobacteria by an immunological comparison of glutamine synthetase and superoxide dismutase. Current Microbiology 4, 133-138.

Brownlee, G. G., Sanger, F. \& Barrell, B. G. (1968). The sequence of $5 S$ ribosomal ribonucleic acid. Journal of Molecular Biology 34, 379-412.

Buchanan, R. E. \& Gibbons, N. E. (1974). Bergey's Manual of Determinative Bacteriology, 8th edn. Baltimore: Williams \& Wilkins.

Chaconas, G. \& Van de Sande, J. H. (1980). 5'-32P labeling of RNA and DNA restriction fragments. Methods in Enzymology 65, 75-85.

Dams, E., Vandenberghe, A. \& De Wachter, R. (1983). Sequences of the 5S rRNAs of Azotobacter vinelandii, Pseudomonas aeruginosa and Pseudomonas fuorescens with some notes on 5S RNA secondary structure. Nucleic Acids Research 11, $1245-1252$.

Delihas, N. \& ANDERson, J. (1982). Generalized structures of the 5S ribosomal RNAs. Nucleic Acids Research 10, 7323-7344. 
Deming, J. W. (1981). Ecology of barophilic deep-sea bacteria. PhD thesis, University of Maryland.

Deming, J. W. \& Colwell, R. R. (1981). Barophilic bacteria associated with deep-sea animals. BioScience 31, 507-511.

Deming, J. W. \& Colwell, R. R. (1982). Barophilic bacteria associated with the digestive tract of abyssal holothurians. Applied and Environmental Microbiology 44, 1222-1230.

DEMING, J. W., TABOR, P. S. \& COLWELL, R. R. (1981). Barophilic growth of bacteria from intestinal tracts of deep-sea invertebrates. Microbial Ecology 7, 8594.

De W achter, R., Chen, M. W. \& Vandenberghe, A. (1982). Conservation of secondary structure in $5 S$ ribosomal RNA: a uniform model for eukaryotic, eubacterial, archaebacterial and organelle sequence is energetically favorable. Biochimie 64, 311-329.

Dietz, A. S. \& Yayanos, A. A. (1978). Silica gel media for isolating and studying bacteria under hydrostatic pressure. Applied and Environmental Microbiology 36, 966-968.

Donis-Keller, H. (1980). Phy-M - an RNAse activity specific for U-residues and A-residues useful in RNA sequence analysis. Nucleic Acids Research 8, 3133-3142.

Donis-Keller, H., Maxam, A. M. \& Gilbert, W. (1977). Mapping adenines, guanines and pyrimidines in RNA. Nucleic Acids Research 4, 2527-2537.

ENGlaNd, T. E., Bruce, A. G. \& UHLENBECK, O. C. (1980). Specific labeling of $3^{\prime}$ termini of RNA with $\mathrm{T}_{4}$ RNA ligase. Methods in Enzymology 65, 65-74.

FoX, G. E. \& WOESE, C. R. (1975). 5S RNA secondary structure. Nature, London 256, 505-507.

Fox, G. E., Stackebrandt, E., Hespell, R. B., Gibson, J., Maniloff, J., Dyer, T. A., Wolfe, R. S., Balch, W. E., TANner, R. S., MAgrum, L. J., Zablen, L. B., Blakemore, R., Gupta, R., Bonen, L., Lewis, B. J., Stahl, D. A., Luehrsen, R. K., Chen, K. N. \& Woese, C. R. (1980). The phylogeny of procaryotes. Science 209, 457-463.

Garrett, R. A., Douthwaite, S. \& Noller, H. F. (1981). Structure and role of 5S RNA-protein complexes in protein biosynthesis. Trends in Biochemical Sciences 6, 137-139.

Gibson, D. W., Hendrie, M. S., Houston, N. C. \& HoBBs, G. (1977). The identification of some Gramnegative heterotrophic aquatic bacteria. In Aquatic Microbiology, pp. 135-159. Edited by F. A. Skinner \& J. M. Shewan. New York: Academic Press.

Hassur, S. M. \& Whitlock, H. H. (1974). UV shadowing - new and convenient method for location of ultraviolet absorbing species in polyacrylamide gels. Analytical Biochemistry 59, 162-164.

HORI, H. \& OSAWA, S. (1979). Evolutionary change in 5S RNA secondary structure and a phylogenetic tree of 54 SS RNA species. Proceedings of the National Academy of Sciences of the United States of America 76, 381-385.

Hugh, R. \& Leifson, E. (1953). The taxonomic significance of fermentative versus oxidative metabolism of carbohydrates by various Gram-negative bacteria. Journal of Bacteriology 66, 24-26.

JanNasch, H. W., Wirsen, C. O. \& TaYlor, C. D. (1982). Deep-sea bacteria: isolation in the absence of decompression. Science 216, 1315-1317.

JORDAN, B. R. (1971). Studies on 5S RNA confor- mation by partial ribonuclease hydrolysis. Journal of Molecular Biology 55, 423-439.

Klotz, L. C., Komar, N., Blanken, R. C. \& MITChEL, R. M. (1979). Calculation of evolutionary trees from sequence data. Proceedings of the National Academy of Sciences of the United States of America 76, 4516-4520.

KomiYa, H., KaWakami, M., Takemura, S., Kumagal, I. \& Erdman, V. A. (1983). Terminal heterogeneity and corrections of the nucleotide sequence of 5S rRNA from an extreme thermophile, Thermus thermophilus HB8. Nucleic Acids Research 11, 913-916.

Kovacs, N. (1956). Identification of Pseudomonas pyocyanea by the oxidase reaction. Nature, London 178, 703.

Kuntzel, H., Heidrich, M. \& Piechulla, B. (1981). Phylogenetic tree derived from bacterial, cytosol and organelle 5S ribosomal RNA sequences. Nucleic Acids Research 9, 1451-1461.

Kuntzel, H., Piechulla, B. \& Hahn, U. (1983). Consensus structure and evolution of SS rRNA. Nucleic Acids Research 11, 893-900.

LI, W. H. (1981). Simple method for constructing trees from distance matrices. Proceedings of the National Academy of Sciences of the United States of America 78, 1085-1089.

LUEHRSEN, K. R. \& Fox, G. E. (1981a). Secondary structure of eukaryotic cytoplasmic $5 \mathrm{~S}$ ribosomal RNA. Proceedings of the National Academy of Sciences of the United States of America 78, 21502154.

LUEHRSEN, K. R. \& Fox, G. E. (1981 b). The nucleotide sequence of Beneckea harveyi SS rRNA. Journal of Molecular Evolution 17, 52-55.

Mackay, R. M., Salgado, D., Bonen, L., Stackebrandt, E. \& Doolittle, W. F. (1982). The 5S ribosomal RNAs of Paracoccus denitrificans and Prochloron. Nucleic Acids Research 10, 29632970.

Mandel, M., Igambi, I., Bergendahl, J., Dodson, M. L. \& SCHELtZen, E. (1970). Correlation of melting temperature and cesium chloride buoyant density of bacterial deoxyribonucleic acid. Journal of Bacteriology 101, 333-338.

MARMUR, J. \& DoTY, P. (1962). Determination of the base composition of deoxyribonucleic acid from its thermal denaturation temperature. Journal of Molecular Biology 5, 109-118.

MaXam, A. M. \& Gilbert, W. (1977). New method for sequencing DNA. Proceedings of the National Academy of Sciences of the United States of America 74, 560-564.

Meyhack, B., Pace, B. \& Pace, N. R. (1977). Involvement of precursor specific segments in in vitro maturation of Bacillus subtilis precursor 5S ribosomal RNA. Biochemistry 16, 5003-5015.

MORITA, R. Y. (1976). Survival of bacteria in cold and moderate hydrostatic pressure environments with special reference to psychrophilic bacteria. In The Survival of Vegetative Microbes, pp. 279-298. Edited by T. G. R. Gray \& J. R. Postgate. Cambridge: Cambridge University Press.

Newhouse, N., Nicoghosian, K. \& Cedergren, R. J. (1981). The nucleotide sequence of phenylalanine rRNA and SS RNA from Rhodospirillum rubrum. Canadian Journal of Biochemistry 59, 921-932. 
Palleroni, N. J., Kunisawa, R., Comtopoula, R. \& DoudorofF, R. (1973). Nucleic acid homologies in the genus Pseudomonas. International Journal of Systematic Bacteriology 23, 333-339.

Peattie, D. A. (1979). Direct chemical method for sequencing RNA. Proceedings of the National Academy of Sciences of the United States of America 76, 1760-1764.

Reichelt, J. L., Baumann, P. \& Baumann, L. (1976). Study of genetic relationships among marine species of the genera Beneckea and Photobacterium by means of in vitro DNA/DNA hybridization. Archives of Microbiology 110, 101-120.

Schwarz, J. R., Yayanos, A. A. \& Colwell, R. R. (1976). Metabolic activity of the intestinal microfiora of a deep-sea invertebrate. Applied and Environmental Microbiology 31, 46-48.

Studnicka, G. M., Eiserling, F. A. \& Lake, J. A. (1981). Computer method for predicting the secondary structure of single stranded RNA. Nucleic Acids Research 5, 3365-3387.

Tabor. P. S., Deming, J. W., Ohwada, K., Davis, H., W AXman, M. \& ColWell, R. R. (1981). A pressureretaining deep ocean sampler and transfer system for measurement of microbial activity in the deep sea. Microbial Ecology 7, 51-65.

Tabor, P. S., Deming, J. W., OhWada, K. \& Colwell, R. R. (1982). Activity and growth of microbial populations in pressurized deep-sea sediment and animal gut samples. Applied and Environmental Microbiology 44, 413-422.
Woese, C. R., Pribula, C. D., Fox, G. E. \& Zablen, L. B. (1975). The nucleotide sequence of the $5 S$ ribosomal RNA from a photobacterium. Journal of Molecular Evolution 5, 35-46.

Yayanos, A. A. (1982). Deep-sea biophysics. In Subseabed Disposal Program Annual Report January to September 1981, vol. II, SAND82-0664/11, pp. 407 426. Edited by K. R. Hinga. Albuquerque: Sandia National Laboratories.

YayanOS, A. A. \& Dietz, A. S. (1982). Thermal inactivation of a deep-sea barophilic bacterium. Applied and Environmental Microbiology 43, 14811489.

Yayanos, A. A., Dietz, A. S. \& Van Boxtel, R. (1979). Isolation of a deep-sea barophilic bacterium and some of its growth characteristics. Science 205, 808-810.

Yayanos, A. A., Dietz, A. S. \& Van Boxtel, R. (1981). Obligately barophilic bacterium from the Mariana Trench. Proceedings of the National Academy of Sciences of the United States of America 78, 5112-5214.

Yayanos, A. A., Dietz, A. S. \& Van Boxtel, R. (1982). Dependence of reproduction rate on pressure as a hallmark of deep-sea bacteria. Applied and Environmental Microbiology 44, 1356-1361.

ZoBell, C. E. \& MoritA, R. Y. (1957). Barophilic bacteria in some deep sea sediments. Journal of Bacteriology 73, 563-568. 